\title{
The Significance of Victim Harm: Booth $v$ Maryland and the Philosophy of Punishment in the Supreme Court
}

\author{
Richard S. Murphy $\dagger$
}

In recent years the so-called "victims' rights movement" has achieved considerable success in increasing the attention that the criminal justice system pays to victims of crime. Examples are as diverse as the substantive reform of rape laws, ${ }^{1}$ enactment of rape "shield" laws, ${ }^{2}$ passage of the Federal Victim and Witness Protection Act, ${ }^{3}$ and the success of organizations such as the National Organization for Victim's Assistance and Mothers Against Drunk Driving. ${ }^{4}$

One consequence of the victims' rights movement is the increasing importance of victim harm in determinations of an offender's sentence. One element of this trend is the use of "victim impact statements," now employed in various forms by thirty-eight states and the federal government. ${ }^{\circ}$ A victim impact statement de-

$\dagger$ B.A. 1986, McGill University, J.D. Candidate 1989, The University of Chicago.

${ }^{1}$ See Leigh Bienen, Rape III-National Developments in Rape Reform Legislation, 6 Women's Rights L Rptr 171 (1980).

2 See J. Alexander Tanford and Anthony Bocchino, Rape Victim Shield Laws and the Sixth Amendment, 128 U Pa L Rev 544 (1980).

3 Pub L No 97-291, 96 Stat 1248 (1982), codified at 18 USC $\S$ 1512-1515, 3579-3580 (1982). The Act amended Federal Rule of Criminal Procedure 32(c)(2). Following passage of the Victim and Witness Protection Act, FRCrP 32(c)(2) provided, "The presentence report shall contain ... (C) information concerning any harm, including financial, social, psychological, and physical harm, done to or loss suffered by any victim of the offense." FRCrP 32 was amended again by Pub L No 98-473 \& 215(a) (1984). The relevant provision, $32(c)(2)(D)$, now provides that the report of the presentence investigation shall contain "verified information stated in a nonargumentative style containing an assessment of the financial, social, psychological, and medical impact upon, and cost to, any individual against whom the offense has been committed."

4 For a brief overview of the victims' rights movement, see Frank Carrington and George Nicholson, The Victims' Movement: An Idea Whose Time Has Come, 11 Pepperdine L Rev 1 (1984). The proliferation of victims' rights prompted the American Civil Liberties Union to publish a handbook: James Stark and Howard Goldstein, The Rights of Crime Victims: Comprehensive and Up-to-Date, a Basic Guide to Victims' Rights Under Today's Laws (Bantam, 1985).

- See Comment, The Relevance of Victim Impact Statements to the Criminal Sentencing Decision, 36 UCLA L Rev 199, 200 (1988); Maureen McLeod, Victim Participation at Sentencing, 22 Crim L Bull 501, 507 n 22 (1986). 
scribes the effect of a particular crime on the victim and his family. ${ }^{6}$ The statement is presented to the sentencing authority who must consider it when imposing punishment.

The prevalence of victim impact statements reveals several assumptions about the purposes of punishment. Punishing the defendant according to the degree of harm caused the victim achieves two utilitarian goals: it permits the victim and society to express their outrage at the evil the defendant caused, and it incrementally deters the underlying criminal conduct. In addition, it is widely believed that achieving the retributive goal of inflicting a "fair" or "deserved" punishment necessitates some consideration of postcrime victim suffering.

That a system of punishment should take into account harm or result is not a radical concept; the criminal law has always categorized crimes and their sanctions according to the actual consequences of the crimes. For example, whether a victim lives or dies often determines the gravity of the offense charged. ${ }^{7}$ Attempts and completed acts are categorized differently, ${ }^{8}$ and the new Federal Sentencing Guidelines consistently make the severity of punishment a function of the harm caused by the offender. ${ }^{9}$

In conflict with this emphasis on the results of conduct is the traditional and in some cases judicially enforced focus on the offender's culpability. The Eighth Amendment prohibition of "cruel and unusual punishments"10 has been the Court's vehicle for such enforcement. Particularly in capital cases, the Supreme Court has attempted to adhere to the retributivist maxim that punishment must be meted out only to the extent "deserved" and cannot be "excessive" or out of proportion to culpability. ${ }^{11}$ Yet this mandated

- For a description of the various types and uses of victim impact statements, see Comment, 36 UCLA L Rev at 202-211 (cited in note 5) and McLeod, 22 Crim L Bull at 510-514 (cited in note 5 ).

' In some cases, the victim's ensuing death will turn a non-criminal act into a criminal one with serious sanctions, as with certain forms of involuntary manslaughter.

${ }^{8}$ In California, for example, an attempt ordinarily carries a maximum penalty of onehalf the maximum term authorized for the completed offense that was attempted. Cal Penal Code $\S 664$ (1986). (Note, however, that California amended $\S 664$ in 1986 to provide for life imprisonment for wilful, premeditated attempted murder. See $\$$ 664(1) (1986).) At common law, attempts were misdemeanors. Some states have eliminated or reduced the traditional difference in sanctions. See, for example, Conn Gen Stat Ann § 53a-51 (1985) and 11 Del Code Ann § 531 (1987). See also, Model Penal Code § 5.05(1) (ALI, 1962).

${ }^{\circ}$ US Sentencing Commission, Federal Sentencing Guidelines and Policy Statements (1987).

${ }^{10}$ US Const, Amend VIII.

11 Moral culpability (or culpability) is used to mean the moral depravity of the defendant's character and underlying conduct. 
focus on the defendant's culpability cannot be theoretically or practically reconciled with the imposition of a particular sanction based solely upon its utility to society or to the victim.

The Supreme Court confronted this conflict in Booth $v$ Maryland. ${ }^{12}$ In Booth, the defendant was convicted of first-degree murder after robbing and killing an elderly couple in their home. The presentence report submitted to the jury contained a victim impact statement that described the severe emotional impact of the crime on the couple's family and set forth the family's opinions and characterizations of the crime. Dividing five to four, the Supreme Court held that the use of a victim impact statement in the sentencing phase of a capital trial violated the Eighth Amendment. The Court reversed the jury's death sentence. ${ }^{13}$

The Booth decision rested on the broad ground that victim impact statements are per se unconstitutional in capital sentencing decisions because the information they contain is irrelevant to the criminal's culpability. ${ }^{14}$ The assumption that a sentencing authority's sole concern should be the criminal's culpability is in accord with most, but not all, ${ }^{15}$ of the Court's capital punishment jurisprudence. The Court's decision in Booth thus provides a convenient framework in which to discuss the central topic of this comment: the tension between society's concern that sentencing be

$12107 \mathrm{~S} \mathrm{Ct} 2529$ (1987).

${ }^{13}$ In Mills v Maryland, $108 \mathrm{~S}$ Ct 1860, 1876 (1988), Chief Justice Rehnquist stated in dissent that he "continue[s] to believe that [Booth] was wrongly decided." Justice Kennedy, who replaced Justice Powell, concurred in this dissent, signaling a possible disagreement with Powell, who cast the deciding vote in Booth. However, it may be premature to attribute this view to Justice Kennedy; Chief Justice Rehnquist's opinion argues in the alternative that even under Booth the government should win in Mills. Id at 1876-1877. The majority in Mills did not reach any of these issues, deciding to reverse the death sentence on other grounds.

16 The Booth decision could be read narrowly as holding that the inflammatory nature of victim impact statements has a prejudicial effect on the jury that justifies their exclusion. Booth, 107 S Ct at 2536, citing Gardner v Florida, 430 US 349, 358 (1977) (opinion of Stevens) (imposition of the death sentence must "be, and appear to be, based on reason rather than caprice or emotion"). This reading of Booth seems inconsistent with the liberal evidentiary rules applicable in the sentencing phase of a trial, however. See Williams v New York, 337 US 241, 248-249 (1949) ("Modern changes in the treatment of offenders make it more necessary now than a century ago for observance of the distinctions in the evidential procedure in the trial and sentencing processes."). Although Williams was limited by Gardner $v$ Florida, 430 US 349 (1977), the concept of liberal evidentiary rules in sentencing remains valid. For a discussion of the broad sentencing inquiry and its limitations, see Comment, Intent After Enmund v Florida: Not Just Another Aggravating Circumstance, 65 BU L Rev $809,818-824$ (1985).

${ }^{15}$ The plurality opinion in Jurek $v$ Texas, 428 US 262 (1976), for example, is inconsistent with Booth's mandated focus on culpability. For a discussion of this inconsistency, see section II.B.2. 
victim-related and the criminal law's general emphasis on result, on the one hand, and the Supreme Court's retributive Eighth Amendment doctrine, on the other hand.

Section I of this comment outlines the two basic theories of punishment, retribution and utilitarianism, and concludes that punishment based on harm or result cannot be justified under a retributive, desert-oriented theory. Section II examines the Supreme Court's Eighth Amendment jurisprudence in light of the two basic theories of punishment detailed in section I. Section III critiques the Court's constitutionalization of retributive theory. Finally, section IV discusses and rejects two potential justifications for the mandated focus on culpability. The comment concludes that the Court's mandated focus on culpability is unjustified.

\section{Victim HaRm and the Theories of Punishment}

Justifications for punishment-why we punish, and why we punish to the extent we do-usually fall into one of two categories: retributive or utilitarian. The volume of literature on penal philosophy is tremendous, ${ }^{16}$ and no attempt will be made to examine in depth the theory underlying either model of punishment. However, because the terminology is inconsistently employed, especially by the courts, and because the Supreme Court has periodically disparaged and revived certain theories, a brief discussion of the two theories is necessary. For purposes of this comment, retribution and utilitarianism are defined to encompass mutually exclusive categories. A particular penalty may have both retributive and utilitarian elements, but the theories in general are in opposition. ${ }^{17}$

\section{A. Retribution}

The basic premise of retribution is that punishment should only be administered to the extent it is deserved. ${ }^{18}$ Punishment must therefore be based upon a moral principle that relates to the individual, not society's needs. The retributivist rejects the notion

${ }^{26}$ For a bibliography, see Joel Feinberg and Hyman Gross, eds, Philosophy of Law 628 (Wadsworth, 2d ed 1980).

- ${ }^{17}$ Some have tried to reconcile the theories. See, for example, John Rawls, Two Concepts of Rules, 64 Phil Rev 3, 5-6 (1955); H.L.A. Hart, Prolegomenon to the Principles of Punishment, reprinted in H.L.A. Hart, Punishment and Responsibility 1 (Oxford, 1968) ("Any morally tolerable account of this institution [of punishment] must exhibit it as a compromise between distinct and partly conflicting principles.").

${ }^{18}$ See Hugo Bedau, Retribution and the Theory of Punishment, $75 \mathrm{~J}$ Phil 601, 608-611 (1978). 
of treating an individual as a means to achieving a social end. Immanuel Kant first set forth the moral basis of retribution:

Juridical Punishment can never be administered merely as a means for promoting another Good either with regard to the Criminal himself or to Civil Society. ... [F]or one man ought never to be dealt with merely as a means subservient to the purpose of another. . . ${ }^{19}$

The elusive goal that punishment be proportional to what the actor deserves lies at the heart of retribution. ${ }^{20}$ The difficulty is in achieving or even defining "proportion." Kant used a "principle of equality":21 one who commits murder is deemed to have willed that murder be a universal rule, applicable to all. As punishment, society must show the murderer what he willed by applying his rule to him and giving him an equal punishment of death.

This theory, in effect, defines a just or proportionate punishment as being equal to the harm the actor intended to cause. There are obvious problems with this definition. Few would suggest, for example, that rape is the appropriate punishment for rape. ${ }^{22}$ This difficulty can be removed (though at some cost to the theory's meaning) if upper limits are placed on the manner, and in extreme cases, the severity of the punishment. If punishments do not transgress certain principles of human dignity, and if a method exists to translate heinous crimes into a roughly equivalent but "dignified," or "usual," penalty, then the Kantian theory is viable even under modern standards. ${ }^{23}$

19 Immanuel Kant, The Philosophy of Law 195 (W. Hastie translation, Augustus M. Kelley, 1887). There is some debate whether this means that utilitarian principles can never be employed, or only that they can never be the sole reason for punishment. See Hart, Punishment and Responsibility at 244 (cited in note 17) (arguing for the latter).

${ }^{20}$ The term retribution derives from the Latin retribuere-to repay. It has been defined in the literature in a variety of ways. Many are consistent with my understanding of a focus on desert or moral culpability. See Andrew von Hirsh, Doing Justice: The Choice of Punishments chs 8, 9 (Hill \& Wang, 1976) (principle of proportionality concerns how much punishment one deserves, which should be commensurate with the degree of blameworthiness of the conduct; blameworthiness depends both on the "characteristic" harmfulness of the conduct and on the degree of culpability of the actor); see also Jeffrie Murphy, Marxism and Retribution, 2 Phil \& Pub Affairs 217 (1973). Some, however, have used retribution to mean what is here termed retaliation or vengeance. See Ted Honderich, Punishment: The Supposed Justifications 15-22 (Harcourt, Brace \& World, 1970) (outlining nine distinct meanings that can be ascribed to the phrase "the criminal deserves punishment").

${ }^{21}$ Kant, The Philosophy of Law at 196 (cited in note 19).

22 See Bedau, $75 \mathrm{~J}$ Phil at 611 (cited in note 18).

2s At least one Justice has interpreted the Eighth Amendment as requiring that punishments remain within the confines of human dignity. See Furman v Georgia, 408 US 238, 281 (1972) (Brennan concurring). 
Regardless of the difficulties in achieving proportionate punishments, the point remains that retribution, as used here, implies punishment scaled to moral culpability. Retribution is often used to refer to and justify punishment meted out as a consequence of the harm suffered by a victim. However, this use of the term "retribution" is misleading. To maintain clarity and to adhere to the theoretical underpinnings of Kant's theory, this comment will use the term "vengeance" to refer to punishment based on consequences. Vengeance is a utilitarian theory and is, by definition, antithetical to retribution in the sense of desert for culpability. ${ }^{24}$ While it is true that retribution may at times resemble vengeance, and that the theory of retribution has often been disparaged as an attempt to justify what is essentially a base human emotion, ${ }^{25}$ retribution, as it is used here, is distinct from vengeance. With retribution, any considerations of the victim or of society, at least after the crime has been committed, are irrelevant.

Although there are several rationales for punishment based on result that attempt to use retributive theory, none is convincing. One is an Aristotelian "balancing of the scales" argument: the victim has suffered a burden, and thus so must the defendant, in order to restore equilibrium. ${ }^{26}$ The effect of this theory is that the state can exact a "payment" equal to the harm that the actor actually caused. The same idea is at work in the damages system of civil law, and has some intuitive appeal. ${ }^{27}$ But such intuitions are mistaken. Why should punishment be scaled to harm? The answer must be either because the offender deserves it, which again begs the question, or because some other, presumably utilitarian goal is served.

It can also be argued that an individual's moral culpability includes responsibility for the harm caused. It is a common belief that an offender should not complain when foreseeable results come about and he is punished for them. But whatever theory exists to justify this belief, it is not retribution..$^{28}$ Under a properly

${ }^{24}$ For an extensive discussion of why actual harm caused is an inadequate basis for retributive punishment, see Stephen J. Schulhofer, Harm and Punishment: A Critique of the Emphasis on the Results of Conduct in The Criminal Law, 122 U Pa L Rev 1497, 15081517 (1974).

${ }^{25}$ See A.C. Ewing, The Morality of Punishment 32-35 (Patterson Smith, 1929)(discussing and refuting the association of retribution with revenge).

${ }^{28}$ This is termed Aristotelian because it is analogous to Aristotle's principle of rectificatory justice. See Feinberg and Gross, eds, Philosophy of Law at 285-286 (cited in note 16).

${ }^{27}$ For an examination of the relationship between restitution and punishment, see Stephen Schafer, Restitution to Victims of Crime (Stevens \& Sons, 1960).

${ }^{28}$ The absence of a theoretical rationale for this intuition is often admitted. See Model 
understood theory of retribution, negligent homicide would not inherently deserve more punishment than attempted murder..$^{29}$ Even where the actor intentionally committed a serious crime, the harm he caused remains irrelevant to achieving a purely proportionate punishment. The actor may be responsible to the victim for the victim's sake, but, focusing on the offender, why should what he deserves depend on the fortuity of whether a foreseeable result actually occurred? "Tough luck" is not a legitimate theory of punishment. $^{30}$

A third possibility is that punishing based on result serves as a proxy for punishing based on individual culpability. Since intentions are often difficult to discern, it might be reasonable to assume that looking to actual consequences would result in more "accurate" sentences on the average than would trying to calculate an individual's precise degree of culpability. This contention proceeds from two assumptions: the more harm an offender causes, the more culpable he probably is; and it is not worth spending additional judicial resources to determine the extent of divergence between result and culpability. This concept will be discussed more fully in section III; at this point, suffice to say that harm is not a good proxy for culpability, nor is it even used as a proxy by the criminal justice system.

In sum, the retribution theory of punishment, as properly understood, focuses on what the defendant deserves, not on what would benefit society. Hence, the Supreme Court's decision in Booth, by holding that victim impact statements are per se irrelevant to the capital sentencing decision, is completely consistent with and in fact required by the retributivist model of punishment.

\section{B. Utilitarianism}

The utilitarian theory of punishment, popularized by Jeremy Bentham ${ }^{31}$ arose out of a desire to alleviate the harsh punishments

Penal Code $\S 2.03$, Comments at 134 (Tentative Draft No 4, 1955).

${ }^{20}$ In other words, theories and intuitions incorporating foreseeability are not based on retribution. See Schulhofer, $122 \mathrm{U} \mathrm{Pa} \mathrm{L} \mathrm{Rev} \mathrm{at} \mathrm{1514-1517} \mathrm{(cited} \mathrm{in} \mathrm{note} \mathrm{24).}$

${ }^{30}$ It is true that foreseeability relates to mens rea, which is in turn relevant to culpability. But the issue is whether victim harm should factor into the calculation of punishment. If there are two offenders, both of whom could foresee a certain result, but the result occurs only for one, should their penalties differ? Whether the predicate mental state (negligence in failing to account for a foreseeable result) is sufficiently culpable to justify a certain sanction is irrelevant to this issue.

${ }^{31}$ See Jeremy Bentham, The Utilitarian Theory of Punishment, in Introduction to the Principles of Morals and Legislation (Dolphin, 1823). 
that were being justified under the guise of retribution and "justice." The basic principle of utilitarianism is that an action should be taken if and only if it serves to increase the total happiness of society. ${ }^{32}$ Deterrence, rehabilitation, and vengeance are examples of mechanisms used to achieve utilitarian goals. ${ }^{33}$

While the retributivist looks backward to the offender's state of mind and his actions, the utilitarian looks forward to decide what course of action will maximize total utility to society. ${ }^{34}$ Since it is an empirical question whether considering the harm in certain instances will have a positive net effect upon society, the impact of a crime upon a victim or upon society is, at the very least, theoretically relevant to the utilitarian calculus.

Theorists have traditionally offered two utilitarian justifications for punishment based on result. First, an increased sanction for causing greater harm deters the underlying illegal conduct. For example, reckless driving will be deterred to some extent because people will seek to avoid the severe penalty that results if one drives recklessly and happens to kill someone. ${ }^{35}$ The problem with this justification is that increasing the penalty for the underlying conduct is a far more efficient way of deterring such conduct. ${ }^{36}$

A second, more forceful, utilitarian justification is that the punishment of the unfortunate speeder who kills satisfies society's need for vengeance and the victim's family's need for vengeance. There are at least two reasons why this vengeance justification might advance social utility: The "escape-valve" version holds that legal punishment is an orderly outlet for aggressive feelings, which would otherwise demand satisfaction in socially disruptive ways

${ }^{32}$ Id at 162. ("The end of law is, to augment happiness.") "Happiness" and "utility" are here used interchangeably.

${ }^{33}$ Though incapacitation may be characterized as another utilitarian reason for punishment, incapacitation is better understood as a subset of deterrence. A criminal will be deterred from committing further crimes while in jail. For a discussion of deterrence generally, see notes 98-106 and accompanying text.

34 John Rawls, Two Concepts of Rules, 64 Phil Rev 3, 5 (1955).

${ }^{35}$ But see Roger C. Cramton, Driver Behavior and Legal Sanctions: A Study of Deterrence, 67 Mich L Rev 421, 431-432 (1969)(arguing that the possibility of a serious accident is so remote as to greatly minimize the deterrent effect of such sanctions).

${ }^{36}$ Schulhofer, $122 \mathrm{U} \mathrm{Pa} \mathrm{L} \mathrm{Rev} \mathrm{at} 1518$ (cited in note 24). There are at least two responses to the contention that an efficient deterrence theory would not differentiate based on harm. First, if the sanctions for simple reckless driving are increased to the necessary level, juries might nullify the law. See Model Penal Code $\$ 2.03$, Comments at 134 (Tentative Draft No 4, 1955); Herbert Wechsler and Jerome Michael, A Rationale of the Law of Homicide II, 37 Colum L Rev 1261, 1265, 1268 (1937). The second response, frugality of punishment, is discussed in section IV. 
such as lynching..$^{37}$ The "hedonistic" version finds the justification simply in the pleasure it gives people to see the criminal suffer..$^{38}$

Of course, it is possible to argue that punishment based on result does not advance social utility, either because vengeful preferences are deemed minimal or short-lived by the utilitarian, or because they are outweighed by the offender's suffering and the potentially anarchic effects of using a vengeance system. Furthermore, if a utilitarian feels that vengeful motives serve no valid social purpose, the family's feelings need not be factored into the social utility calculus. ${ }^{\text {s9 }}$ But dismissing certain preferences necessarily implies a mechanism for distinguishing between "legitimate" and "illegitimate" preferences.

Distinguishing between preferences could presumably be done by evaluating the reason for holding the preference and eliminating irrational preferences. Victims and society demand stiff penalties because they believe the defendant deserves the punishment for causing the death. Though most theories of desert or retribution would make actual harm irrelevant, it is by no means obvious that such a belief is irrational. It would be difficult to argue that society's preferences should be ignored simply because they are not in accord with Kantian retribution theory, especially since the utilitarians themselves reject such a theory.

Thus, under the utilitarian approach, victim harm is pertinent to a sentencing decision. Both deterrence and vengeance enable one to make credible arguments in favor of punishing in proportion to harm. It is only if one adopts a retributive theory of punishment that harm becomes unequivocally irrelevant to the sentencing decision.

${ }^{37}$ See Furman v Georgia, 408 US 238, 308 (1972) (Stewart concurring); James Stephen, 2 A History of the Criminal Law of England 75-83 (McMillan, 1883); Oliver Wendell Holmes, Jr., The Common Law 41-42 (Little, Brown, 1881).

${ }^{38}$ See Feinberg and Gross, eds, The Philosophy of Law at 520 (cited in note 16). For a critique of these theories, see Schulhofer, $122 \mathrm{U} \mathrm{Pa} \mathrm{L} \mathrm{Rev} \mathrm{at} \mathrm{1511-1514} \mathrm{(cited} \mathrm{in} \mathrm{note} \mathrm{24).}$

39 The classic utilitarian formula implies acceptance of preferences as they are, not as they ought to be. For example, a rule permitting public executions would be desirable under classic utilitarianism if the people's increased happiness from watching the executions was greater than any countervailing suffering, or decrease in utility. Bentham countered this problem by averring that such rules would always be inefficacious. H.L.A. Hart, Punishment and Responsibility at 19 (cited in note 17). But most modern utilitarians admit the necessity of importing an external limiting principle into the calculus. See, for example, Thomas Schwartz, Human Welfare, What It Is Not, in Harlan B. Miller and William H. Williams, eds, The Limits of Utilitarianism (1982). 


\section{Eighth Amendment Jurisprudence and the Legitimate Justifications of Punishment}

The Eighth Amendment's prohibition against "cruel and unusual punishments" ${ }^{40}$ was originally interpreted as barring methods of punishment that were excessively painful, or that exceeded the bounds of human decency. ${ }^{41}$ Since political checks proved effective in preventing such barbaric punishments, for many years the Eighth Amendment went largely unused by the Court. ${ }^{42}$ Thus, the Court did not inquire into the possible legislative purposes behind a given punishment.

With the expansion of Eighth Amendment protections through the landmark cases of Weems $v$ United States ${ }^{43}$ and much later Furman $v$ Georgia, ${ }^{44}$ the purposes or theories behind punishment gradually became relevant to Eighth Amendment doctrine. Presently, if a punishment makes no contribution to acceptable or legitimate penal goals, it is unconstitutional under the Eighth Amendment. ${ }^{45}$ Thus, the Court's view on whether a certain theory is legitimate can be determinative of the constitutionality of a sentencing procedure or specific penalty.

Until the early twentieth century, the Court said little about the goals or theories of punishment. ${ }^{46}$ However, with the rise of rehabilitation as a seemingly viable and humane basis for a system of punishment, the Court began to express some dissatisfaction with the theory of retribution. ${ }^{47}$ Nevertheless, the Court has never

${ }^{10}$ US Const, Amend VIII. The full text of the amendment provides, "Excessive bail shall not be required, nor excessive fines imposed, nor cruel and unusual punishments inflicted." The language of the amendment was "an exact transcript of a clause in the [English] bill of rights, framed at the revolution of 1688." Joseph Story, 3 Commentaries on the Constitution $\$ 1896$ (De Capo, 1970).

${ }^{41}$ See Wilkerson v Utah, 99 US 130, 135-136 (1878); Pervear v Commonwealth, 72 US 475,480 (1867). This view is entirely consistent with the framers' intentions. See, for instance, Patrick Henry's speech at the Virginia Convention, 3 J. Elliot's Debates 446-448 (Taylor \& Maury, 2d ed 1876), cited in Furman $v$ Georgia, 408 US at 320-321 (Marshall concurring). But see O'Neil v Vermont, 144 US 323, 339-340 (1892) (Field dissenting)(Eighth Amendment bars more than just torture; it also prohibits disproportionate penalties).

${ }^{12}$ For a concise history of the Eighth Amendment, see Furman, 408 US at 316-326 (Marshall concurring).

4217 US 349 (1910).

14408 US 238 (1972).

45 Coker v Georgia, 433 US 584, 592 (1977) (plurality opinion of White), citing Gregg $v$ Georgia, 428 US 153, 173 (1976) (plurality opinion of Stewart).

${ }^{16}$ But see O'Neil, 144 US at 339-340 (1892) (Field dissenting) (arguing that the Eighth Amendment prohibits "all punishments which by their excessive length or severity are greatly disproportioned to the offences charged").

${ }^{17}$ In Williams $v$ New York, the Court stated "Retribution is no longer the dominant 
advocated eliminating retribution completely. ${ }^{48}$ With the recent widespread perception that rehabilitation efforts have failed dramatically, ${ }^{49}$ and with the revival in the commentaries of retribution as a favored goal of punishment, ${ }^{50}$ the debate in the Court over the "legitimacy" of retribution has waned.

The Court's views on the legitimacy of vengeance are more difficult to discern. The Court seems to have rejected any utilitarian justifications other than deterrence: "Unless the death penalty ... measurably contributes to one or both of [retribution and deterrence], it 'is nothing more than the purposeless and needless imposition of pain and suffering,' and hence an unconstitutional punishment." "51 Any discussion based on the Court's language has questionable validity, however, because the Court often uses the term "retribution" to include society's outrage or the victim's concerns. The Court has not ventured a precise definition of retribution, and only Justice Marshall has differentiated retribution from vengeance. ${ }^{52}$ Therefore, this section focuses on what the Court has done, rather than what it has said, often in dicta, about retribu-

objective of the criminal law. Reformation and rehabilitation of offenders have become important goals of criminal jurisprudence." 337 US 241, 248 (1949). Williams is pertinent to Booth because, though approving of the rehabilitative model of punishment, the Court upheld an execution, allowing a trial judge broad discretion in the evidence he or she considers when deciding on a punishment. The status of Williams is in some doubt. See note 14.

48 Several Justices have taken the position that retribution is flatly impermissible. Justice Marshall attacked "pure" retribution as a justification for the death penalty, stating that "the taking of life 'because the wrongdoer deserves it' surely must fall, for such a punishment has as its very basis the total denial of the wrongdoer's dignity and worth." Gregg $v$ Georgia, 428 US 153, 240-241 (1976) (Marshall dissenting). Justice Goldberg failed to list retribution as one of the "permissible aims" of a penal system. Rudolph v Alabama, 375 US 889, 891 (1964) (Goldberg dissenting from denial of cert). Several opinions in Furman approved of retribution not on moral grounds, but because of the utilitarian goals that retribution purportedly achieves. See, for example, Furman, 408 US at 308 (Stewart concurring); Id at 453 (Powell dissenting)("While retribution alone may seem an unworthy justification in a moral sense, its utility in a system of criminal justice requiring public support has long been recognized." (emphasis added)). The Kantian concept of retribution as an individual right to not be used as a tool for greater societal ends has eluded explication in the Supreme Court, or at least this right has not been connected with the retributive aims of punishment.

19 See, for example, Leslie Sebba, The Victim's Role in the Penal Process: A Theoretical Orientation, $30 \mathrm{Am}$ J Comp L 217, 230 (1982) ("rehabilitation has become almost an obscenity"); Andrew von Hirsh, Doing Justice 14 (Hill \& Wang, 1976) ("A wide variety of rehabilitation programs have now been studied. A few successes have been reported, but the overall results are disappointing.").

so Sebba, $30 \mathrm{Am} \mathrm{J}$ Comp L at 230 (cited in note 49).

${ }^{31}$ Enmund v Florida, 458 US 782, 798 (1982), quoting Coker, 433 US at 592. See also Furman, 408 US at 394 (Burger dissenting).

${ }_{32}$ See, for example Furman, 408 US at 304 (Brennan concurring) (equating "naked vengeance" with retribution); but see Gregg v Georgia 428 US at 240-241 (Marshall dissenting) (differentiating between vengeance and retribution). 
tion. Part A examines how the holding in Booth fits into the Court's retributive Eighth Amendment jurisprudence. Part B examines some theoretical implications of that jurisprudence including whether it is consistent with a deterrence rationale.

\section{A. Booth and Eighth Amendment Jurisprudence}

As applied to the death penalty, Eighth Amendment doctrine consists of two distinct branches, one procedural and one substantive. The Court's holding in Furman v Georgia, ${ }^{53}$ which brought the death penalty under the auspices of the Eighth Amendment, ${ }^{54}$ created the procedural facet. The precise grounds upon which the death penalty statute in Furman was struck down were clouded since nine opinions were rendered. Subsequent cases such as Gregg $v$ Georgia $^{55}$ and Woodson $v$ North Carolina ${ }^{56}$ help to clarify the standards. Presently, capital punishment violates the Eighth Amendment if imposed pursuant to procedures that result in "capricious" or "arbitrary" executions-that is, where there is "no principled way to distinguish [cases] in which the death penalty was imposed, from the many cases in which it was not." 57 The substantive requirement, following Weems v United States, ${ }^{58}$ bars an execution if it is an inherently disproportionate or excessive penalty for a particular crime. ${ }^{59}$

53408 US 238 (1972).

s4 Theoretically, before Furman an execution could have violated the Eighth Amendment either because it was carried out in a cruel manner or because it was disproportionate to a given crime under Weems v United States, 217 US 349 (1910). But the Court never invalidated executions under either standard. See Wilkerson v Utah, 99 US 130 (1879) (public execution by shooting is constitutional); Louisiana ex rel Francis $v$ Resweber, 329 US 459 (1947) (following a failed attempt at electrocution, a second attempt is constitutional).

${ }^{85} 428$ US 153 (1976).

${ }^{58} 428$ US 280 (1976).

37 Godfrey $v$ Georgia, 446 US 420, 433 (1980)(plurality opinion of Stewart).

${ }^{s 8} 217$ US 349 (1910). See also Coker v Georgia, 433 US 584, 592 (1977) (plurality opinion of White).

${ }^{59}$ These procedural and substantive requirements do not parallel the Court's usual explication of the two facets of the Eighth Amendment applicable in both capital and noncapital cases. In Coker, 433 US at 592, Justice White summarized the prevailing Eighth Amendment doctrine as follows:

[P] unishment is "excessive" and unconstitutional if it

(1) makes no measurable contribution to acceptable goals of punishment and hence is nothing more than the purposeless and needless imposition of pain and suffering; or

(2) is grossly out of proportion to the severity of the crime.

This comment does not use the Court's two-pronged structure because the first prong is superfluous. Contributing to the acceptable goals of punishment means contributing to either retribution or deterrence. Enmund v Florida, 458 US 782, 798 (1982). The second crite- 


\section{Eighth Amendment procedural requirements.}

In Furman, the Court held that the death penalty may not be imposed under sentencing procedures that create a substantial risk that the punishment will be inflicted in an arbitrary or capricious manner. In essence, the Furman holding implies that equal protection concepts are embedded in the cruel and unusual proscription of the Eighth Amendment. ${ }^{60} \mathrm{~A}$ capital defendant has a heightened right to procedural fairness that requires the state to make principled distinctions between those who receive the death penalty and those who do not. ${ }^{.1}$ The Furman court decided that the Georgia death penalty statutes, in leaving the capital decision to the unbounded discretion of the jury, did not provide sufficient procedural protection.

Competing with this principle of consistency or non-arbitrary results is the goal of flexibility. ${ }^{62}$ In Woodson $v$ North Carolina, ${ }^{63}$ the Court held that automatic death sentences also violate the constitution. Thus, a principle of "guided discretion" appeared, whereby a jury is given a list of aggravating and mitigating circumstances on which to base its decision.

This heightened procedural right, arising because of the unique nature of the death penalty, yielded a series of cases mandating certain procedures: Gardner $v$ Florida ${ }^{64}$ which extended the right to deny or explain evidence presented at sentencing, Lockett $v$ Ohio ${ }^{65}$ which extended the right to have all potential mitigating circumstances considered, and Zant $v$ Stephens, ${ }^{66}$ which explained in dictum that at least one aggravating factor may be required. Because this branch of Eighth Amendment jurisprudence

rion, proportionality, mandates that a sanction be roughly tailored to culpability-that is, it must contribute to the retributive aim of punishment. Thus, since failing under (2) implies failing under (1), the only relevant question is the second: whether the sanction is in gross proportion to the severity of the crime. The Court has never struck down a sentence on the grounds that, though proportionate, it does not contribute to the legitimate aims of punishment.

The Court has made a distinction, however, between invalidating procedural mechanisms that systematically yield capricious results, and making a substantive determination that the death penalty is inherently excessive for a given crime or category of crimes.

${ }^{60}$ Furman, 408 US at 249 (Douglas concurring).

61 Gardner v Florida, 430 US 349, 358 (1977) (plurality opinion of Stevens). See Comment, 65 BU L Rev at 820 (cited in note 14).

\$2 See Note, Distinguishing Among Murders When Assessing The Proportionality of the Death Penalty, 85 Colum L Rev 1786, 1787-1794 (1985).

(3) 428 US 280 (1976).

6. 430 US 349 (1977).

63438 US 586 (1978).

${ }^{86} 462$ US 862, 876, 878 (1983). 
is procedural, if a state's procedures are not systemically defective an offender has no remedy even if occasional sentences are arbitrary or based on illegitimate factors. ${ }^{67}$ That results will be occasionally arbitrary is an inevitable consequence of a jury system. ${ }^{68}$

Despite its language, the Booth Court did not rely on the procedural requirements of the Eighth Amendment in rejecting victim impact statements. The Court held that the harm that an offender caused to the victim's family is capricious in the sense of being beyond the control of the defendant. Using a victim impact statement would result in "arbitrary" impositions of the death penalty, because whether the victim's family undergoes more or less suffering is not a function of the defendant's culpability. ${ }^{69}$ Nonetheless, it is one thing to say that the harm caused by an offender is unrelated to culpability or wickedness; it is quite a different thing to say that harm is irrelevant. It is not true, as the Court claimed, that when the impact on the victim is considered, "there is no principled way to distinguish [cases] in which the death penalty was imposed, from the many cases in which it was not." a distinguishing principle: the harm the victims suffered. The results of imposing the death penalty based on the harm suffered by the victim would not be systemically random or arbitrary unless one accepts the position that procedures should be examined only in light of the offender's culpability. Thus, the critical facet of the Court's decision is the underlying substantive assumption that culpability should be the sole focus.

\section{The substantive proportionality requirement of the Eighth Amendment.}

The Booth Court's substantive conclusion about the exclusive relevance of culpability in a capital sentencing decision is an extension of the Supreme Court's proportionality cases. This line of cases requires that the death penalty be "inherently" in proportion to the crime committed. ${ }^{71}$ In Booth, the Court held that the impact

${ }^{87}$ See Pulley v Harris, 465 US 37, 54 (1984) ("Any capital sentencing scheme may occasionally produce aberrational outcomes. Such inconsistencies are a far cry from the major systemic defects identified in Furman."); McCleskey $v$ Kemp, 107 S Ct 1756, 1777-1781 (1987).

${ }^{68}$ Ordinarily the jury makes the capital sentencing decision, but the same principle applies if the decision is made by a judge. Any amount of discretion inevitably yields some unwanted or inconsistent results.

68 Booth, $107 \mathrm{~S} \mathrm{Ct}$ at 2534 .

${ }^{70}$ Id, citing Godfrey, 446 US at 433.

71 Note that the Supreme Court's doctrine of inherent proportionality is distinct from 
on the victim's family is irrelevant because the actual harm caused is not of itself relevant to moral guilt. The belief that moral guilt should be the central focus of any scheme of punishment lies behind the requirement that punishments be in proportion to the severity of the crime. It is these proportionality cases-Weems $v$ United States, ${ }^{72}$ Coker $v$ Georgia, ${ }^{73}$ Enmund $v$ Florida, ${ }^{74}$ and Tison $v$ Arizona ${ }^{75}$ _that reveal the Court's retributive philosophy. Essentially, the present meaning of Weems and its progeny is that punishment must be roughly scaled to culpability-it must be retributive in nature and not utilitarian.

Weems was the first case to expand Eighth Amendment analysis beyond an examination of whether the method of punishment was inherently cruel or excessively painful. The defendant in Weems had falsified a public document. Pursuant to the Philippine Code, ${ }^{78}$ he was sentenced to fifteen years of hard and painful labor, with his ankles in chains, and to a loss of certain liberties for life. Referring to the Eighth Amendment, the Court first noted that "a principle to be vital must be capable of wider application than the mischief which gave it birth." Th The Court then reversed the sentence, stating that punishments that "by their excessive length or severity are greatly disproportionate to the offense charged"78 violate the Eighth Amendment. ${ }^{79}$ Under similar reasoning, the Court in Coker held that the death penalty was an inherently excessive punishment for rape. ${ }^{80}$

comparative proportionality review, a procedure undertaken by many state Supreme Courts to help ensure consistent application of the death penalty. Comparative proportionality review is not constitutionally required. Pulley $v$ Harris, 465 US 37, 44-51 (1984).

72217 US 349 (1910).

73433 US 584 (1977).

74458 US 782 (1982).

${ }^{75} 107$ S Ct 1676 (1987).

${ }^{78}$ In 1910, the Philippines was a protectorate of the United States. The relevant Philippine law was nearly identical to the Bill of Rights in the U.S. Constitution, and had the same meaning. Kepner $v$ United States, 195 US 100, 124 (1904).

77 Weems, 217 US at 373.

${ }_{78}$ Id at 371, quoting O'Neil $v$ Vermont, 144 US 323, 339-340 (1892) (Field dissenting).

79 The unusual nature of the penalty (involving painful labor) was perhaps as important to its constitutional deficiency as the length of sentence (see Weems, 217 US at 363367 ), but subsequent interpretation has emphasized the excessive element, and now simple imprisonment can be disproportionate to a minor offense. Solem v Helm, 463 US 277, 28490 (1983).

so Justice Powell concurred in the judgment but raised some objections pertinent to Booth. He maintained that "[t]he deliberate viciousness of the rapist may be greater than that of the murderer," and opposed drawing a "bright line between murder and all rapes-regardless of the degree of brutality of the rape or the effect upon the victim." Coker, 433 US at 603. 
Enmund involved a defendant convicted under the felony murder doctrine and sentenced to death after his co-felons had killed during the course of a robbery. The defendant was the getaway car driver, and was not present for the killings. The Court, dividing five to four, overturned the sentence, holding that the death penalty is inherently disproportionate when imposed upon one who "does not himself kill, attempt to kill, or intend that a killing take place or that lethal force will be employed."

In Tison $v$ Arizona ${ }^{82}$ the Court held that the Enmund proportionality requirement only applied to the "minor actor" who had "no culpable mental state." ${ }^{3}$ The Tison defendants helped their father break out of a state penitentiary. In the course of their escape, their car broke down in an Arizona desert. They waived down a passing car carrying four passengers. The passengers were taken to a secluded spot and forced to stand in front of their car. When the victims requested that they not be deserted without water, the father asked the sons to go to the disabled car (parked next to the victims' car) and get water. While the sons were getting the water, the father shot all four of the victims. The killings provoked a huge outcry in Arizona, ${ }^{84}$ in part because one of the victims was a two-year old child. Since the father had died in the desert, only the sons were tried. Upon conviction under the felonymurder doctrine, they were sentenced to death. The Court upheld the sentences, ${ }^{85}$ ruling that the death penalty is permissible where the defendant exhibited "reckless indifference to human life," even if there was neither an intent to kill nor an actual killing by the defendant..$^{86}$

Though the Booth dissent argued that Tison and Booth are difficult to reconcile, ${ }^{87}$ the cases are in fact consistent. Booth demands a focus on culpability. The Tison Court also focused on culpability and determined that "reckless indifference" could be a

s1 Enmund, 458 US at 797.

s2 107 S Ct 1676 (1987).

${ }^{83}$ Id at 1684.

st Id at 1689 (Brennan dissenting) ("Many in Arizona erupted 'in a towering yell' for retribution and justice.").

ss The Court again divided five to four. Justice White, who wrote the opinion in Enmund, joined the Enmund dissenters to form the majority in Tison.

${ }^{86}$ Tison, $107 \mathrm{~S} \mathrm{Ct}$ at 1688. It is questionable whether Tison and Enmund are in fact reconcilable. It is possible that the Court in Tison was considering, sub silentio, the moral outrage provoked by the killings. If this is the case, then Tison clearly does not square with Booth because under Booth, those considerations would be irrelevant.

${ }^{87} 107 \mathrm{~S} \mathrm{Ct}$ at 2541-42 (Scalia dissenting). 
sufficiently culpable state of mind to permit the death penalty..$^{88}$ One might object that the Tison brothers, who were only recklessly indifferent to human life, may be executed, whereas Booth, an intentional killer, might not be. But in fact the lesson of the two cases is that both Booth and the Tisons may be executed, provided the sentencing decision is made with reference only to culpability. ${ }^{89}$

\section{B. Booth and Punishment Theory: Proportionality and} Deterrence

The Court has repeatedly called retribution and deterrence the two legitimate bases for punishment. ${ }^{90}$ This section discusses the role of deterrence in light of the proportionality rule and the generally retributive philosophy evinced in Booth.

\section{The meaning of proportionality.}

The Court's requirement that punishments must be proportional to the offense can be interpreted in two ways. It might be concerned only with culpability; that is, the state could not punish an offender grossly out of proportion to his culpability or "wickedness." This interpretation engrafts the retributive theory onto the Eighth Amendment and makes exclusive reliance upon deterrence, or any other utilitarian theory, impermissible. If it is assumed that actual harm caused is irrelevant to culpability, the holding in Booth would be entirely consistent with this retributive interpretation of the proportionality requirement.

An interpretation of proportionality that requires a focus solely on moral culpability has considerable support in the Supreme Court's decisions. Modern death penalty jurisprudence emphasizes identification of the most culpable defendants. In Enmund, the Court stated that sentencing evidence must have some bearing on the defendant's "personal responsibility and moral guilt." In Zant $v$ Stephens, the Court emphasized that a jury must make an "individualized determination" of whether the de-

ss If is not accepted that the Tison brothers had substantial involvement in the killings, then the Tison Court simply misapplied its own rule.

80 The facts of Tison illustrate a major flaw with the Booth principle that the resultant harm is arbitrary and thus irrelevant to the sentencer. In Tison, it was arbitrary or fortuitous from the sons' points of view that their father shot the victims. The harm caused is always partially fortuitous. This problem is examined more fully in section III.C.

๑0 Enmund, 458 US at 798; Gregg, 428 US at 183 (plurality opinion of Stewart).

91 Enmund, 458 US at 801. 
fendant should be executed based on "the character of the individual and the circumstances of the crime."

Another possible interpretation of proportionality includes the harm caused. That is, a sentence does not violate the Eighth Amendment if it is in proportion to culpability and the harm wrought by the offender and suffered by the victim. Under this interpretation, vengeance could be a legitimate basis for punishment.

There is support for this position as well. The Weems Court emphasized the minimal harm to society that results from falsifying a document. ${ }^{93}$ The Coker plurality explicitly included harm as relevant to the proportionality of punishments. Justice O'Connor wrote in Enmund, "Coker teaches, therefore, that proportionality-at least as regards capital punishment-not only requires an inquiry into contemporary standards as expressed by legislators and jurors, but also involves the notion that the magnitude of the punishment imposed must be related to the degree of the harm inflicted on the victim, as well as to the degree of the defendant's blameworthiness." While admitting that rape is "highly reprehensible, both in a moral sense and in its almost total contempt for the personal integrity and autonomy of the female victim,"95 the plurality in Coker decided that "in terms of moral depravity and of the injury to the person and to the public, it does not compare with murder."

\section{The role of deterrence.}

Either of the above interpretations of proportionality necessarily weakens a deterrence rationale, despite the widespread assumption that deterrence is a valid reason for punishment. If deterrence is indeed valid, the Court's jurisprudence creates two problems. First, the Court has not articulated a rationale for distinguishing deterrence from other utilitarian justifications for punishment. Although there are certainly arguments for considering certain preferences, such as safety, but not others, such as vengeance, the distinction between preferences is far from obvious and

92462 US 862,879 (1983)(emphasis in original). See also Eddings $v$ Oklahoma, 455 US 104, 112 (1982).

s3 Weems, 217 US at 381.

${ }^{24}$ Enmund, 458 US at 815 (O’Connor dissenting) (emphasis added).

${ }^{25}$ Coker, 433 US at 597 (plurality opinion of White).

${ }^{96}$ Id at 598 (emphasis added). Admittedly, Justice White might have meant that only the degree of harm intentionally inflicted on the victim was relevant. 
remains unexplored by the Court. Second, if deterrence is itself a legitimate basis for punishment, as the Court seems to indicate, ${ }^{97}$ and if a sanction deters effectively, then that sanction need not be in proportion to culpability. This conclusion, however, contradicts the holdings of the proportionality cases.

The deterrent effect on rational actors is simply the product of the probability of apprehension and the severity of sentence. ${ }^{88}$ If the probability of apprehension is very low, then the sentence must be relatively severe if a state wishes to compel obedience to a law. But, under Weems, a state can only do this within the bounds of "gross proportionality." If, for example, the Philippines could demonstrate that it is very difficult and costly to catch those who falsify public documents, that falsifying documents was a widespread practice, and that in order to reduce the problem, a penalty such as the one Weems received was necessary, the Philippines still could not impose such a punishment. This is because the punishment as imposed on the particular offender would be out of proportion to his offense.

Notwithstanding Booth ${ }^{99}$ and the trend toward focusing on culpability, the Court has permitted the admission of evidence irrelevant to the defendant's culpability. This suggests that non-retributive theories may in practice be legitimate, even as applied to capital sentencing. For example, the Court claims that the presence or absence of a marginal general deterrent effect is a relevant consideration when analyzing the issue of inherent proportionality. ${ }^{100}$ Furthermore, under Jurek $v$ Texas ${ }^{101}$ the likelihood that a defendant will commit additional crimes (that is, the need for incapacitation or special deterrence ${ }^{\mathbf{1 0 2}}$ ) is a constitutionally acceptable

${ }^{97}$ See note 51 and accompanying text.

${ }^{28}$ This assumes risk-neutral actors. Strictly speaking, the deterrent effect depends as well on the risk preference of the actor and the time value of his freedom. See Frank Easterbrook, Criminal Procedure as a Market System, $12 \mathrm{~J}$ Legal Stud 289, 292-295 (1983).

"Even the Booth Court admitted that the "Court has never said that the defendant's record, characteristics, and the circumstances of the crime are the only permissible sentencing considerations." Booth, $107 \mathrm{~S} \mathrm{Ct}$ at 2532 (emphasis in original). But if these factors-which essentially amount to the definition of culpability-are not the only ones, then a sentence that is disproportionate to culpability should be permissible if based on legitimate non-retributive factors. Further, the Booth Court offered no examples of legitimate factors and, in fact, contradicted itself by holding victim impact statements inadmissable because they contain information irrelevant to culpability.

${ }^{100}$ See Enmund v Florida, 458 US 782, 799-800 (1982).

101428 US 262 (1976).

${ }^{102}$ The special deterrent effect is the deterrent effect on the individual offender, as distinct from the general deterrent effect, which operates on society as a whole. The greater the likelihood of recidivism, the more utility there is in incapacitating the offender. 
criterion for imposing the death penalty. ${ }^{103}$ Clearly, this forwardlooking, utilitarian concern of special deterrence does not relate to the culpability of the defendant. ${ }^{104}$

For punishment less severe than death, of course, there is a range within which a legislature could adjust the sanction in order to achieve some utilitarian goal. ${ }^{105}$ Moreover, incidental deterrence is obviously permissible; it may be that in most cases, punishing in proportion to culpability as perceived by society is the most effective deterrent. ${ }^{106}$

Despite these indications that deterrence is a legitimate goal of punishment, the trend in the Court, culminating in Booth, has been to require more than simply a rough comportment with culpability. According to the reasoning in Booth, the specific capital sentencing decision must be made with reference only to factors that bear on culpability. This is a small theoretical step, since if the proportionality rule were strictly enforced, in effect all sentencing decisions would have to be made with reference only to culpability. But the proportionality rule ordinarily operates only as a very crude check. Hence a mandated focus on culpability is a significant development in practice, and has the effect of rejecting deterrence as a legitimate rationale for punishment.

\section{The Rejection of Victim Suffering as a Basis of Punishment}

The decision in Booth is predicated upon the Court's understanding that a sentencing authority must focus on the defendant's culpability-punishment must be retributive. The question considered in this section is whether such an understanding of the Eighth Amendment, as precluding utilitarian considerations, is justified.

\section{A. Proportionality as a Constitutional Rule}

The Eighth Amendment does not speak to why a state is permitted to punish; it was intended to preclude inhumane punish-

${ }^{103} 428$ US 262, 274-76 (1976), reaffirmed in Barefoot $v$ Estelle, 463 US 880, 896 (1983).

${ }^{104}$ It is insufficient to argue that an offender is more culpable if contemplating future criminal acts; prediction of recidivism involves a statistical or psychological analysis of proclivity to commit future crimes, not contemplation of those crimes. Jurek is inconsistent with Booth's required focus on moral culpability.

${ }^{103}$ In non-capital cases, greater deference is afforded legislatures. See Rummel $v$ Estelle, 445 US 263, 272 (1980); Solem v Helm, 463 US 277, 289-290 (1983).

${ }^{106}$ See US Sentencing Commission, Federal Sentencing Guidelines and Policy Statements 1.3-1.4 (1987). 
ments, not the "serpent-windings of [u]tilitarianism." contemporaneous evidence indicates that the English Bill of Rights, in using language that was later adopted in the Eighth Amendment, ${ }^{108}$ intended to encompass the principle of proportionality. Only three months after the English Bill of Rights was adopted, the House of Lords declared that a "fine of thirty thousand pounds, imposed by the Court of Kings Bench upon the earl of Devon was excessive and exorbitant, against magna charta, the common right of the subject, and the law of the land." ${ }^{109}$ Furthermore, Blackstone, in describing "punishments of unreasonable severity," employed the term "cruel" to mean severe or excessive.110 A sanction that is excessive is a sanction that is in some sense disproportionate to the offense. ${ }^{111}$

A more general argument can be made that focusing on culpability is an inevitable consequence of a rights-based system. The Bill of Rights protects defendants against unjustified incursions by the state; unless the interests of the citizen whose rights are being infringed trump the interests of state or society, rights become meaningless. Perhaps this just begs the question of whether an incursion is unjustified. But the Eighth Amendment is an absolute right. It is problematic to define the parameters of such a right in terms of the utilitarian needs of society. ${ }^{112}$

As a matter of original intent, however, the proportionality rule inherent in the Eighth Amendment does not imply that the practice of scaling punishment to harm is illegitimate. The framers did not reject vengeance and social catharsis as legitimate social objectives. Rather, the original understanding of proportionality was that punishment should be in proportion to the crime, which is a function of both culpability and harm inflicted or suffered. This interpretation is clear from an examination of the method, extent, and theory of punishment prevailing in the eighteenth century. ${ }^{113}$

${ }^{107}$ The phrase is Kant's. The Philosophy of Law 195 (W. Hastie translation, Augustus M. Kelley, 1887).

${ }^{108}$ See $1 \mathrm{Wm} \&$ Mary, sess 2, ch 2 (1689). Notes 108-110 are cited in Solem v Helm, 463 US 277, 285 (1983).

${ }^{109}$ Earl of Devon's Case, 11 State Trials 133, 136 (1689).

${ }^{110}$ William Blackstone, 4 Commentaries *16-" 17 (Chicago, 1979).

${ }_{111}$ See Richard L. Perry, ed, Sources of Our Liberties 236 (Am Bar Found, 1959).

112 See Jeffrie Murphy, Marxism and Retribution, 2 Phil \& Pub Affairs 217, 220 (1973) ("What the Utilitarian theory cannot capture . . . is the notion of persons having rights.")

${ }^{113}$ See Michael Ignatieff, $A$ Just Measure of Pain, ch 2 (Pantheon, 1978). Although the theory of punishment was undergoing a transformation in the late Eighteenth Century, see Henry Elmer Barnes, The Story of Punishment, ch 5 (Patterson Smith, 1972), there is no 
Of course, originalist constitutional theory is far from being universally accepted. But as the following sections indicate, the current consensus on the relevance of harm does not depart from the original understanding of the purposes and limits of punishment.

\section{B. Deference}

One consequence of the proportionality rule is that not only are proportionate punishments required, but the Supreme Court decides what punishments are proportionate. That is, even if a legislature is being retributive and attempting to inflict a "deserved" punishment by considering only the defendant's culpability, it is still subject to judicial review. This review of legislative or state court sentencing determinations is theoretically sound. When criminal defendants cannot expect that the political process will protect their rights, the argument for strict judicial review is at its strongest. Legislators are generally sympathetic to victims' rights and anti-crime advocates and can easily pass statutes inflicting punishments that are "deserved" by no definition except their own. Hence the dissent's call in Booth for greater deference ${ }^{114}$ initially seems misplaced.

The difficulty comes in deciding in any given case whether a sanction is inherently disproportionate. Since the Court has been either unable or unwilling to employ the Kantian "principle of equality,"11s it has used a combination of a visceral sense of proportionality and a survey of society's prevailing attitudes on the imposition of the given penalty. The latter method makes the Court's intrusion on legislative decisions much more palatable.

All three of the capital cases dealing with proportionality-Coker, Enmund, and Tison-attempted to find an empirical basis for the proportionality calculus. The Coker plurality noted that "these Eighth Amendment judgments should not be, or appear to be, merely the subjective views of individual Justices; judgment should be informed by objective factors to the maximum possible extent." 116 In Enmund, the Court undertook an extensive

evidence that the reformers or the Framers intended to purge considerations of victim harm from sentencing.

${ }^{114}$ Booth, $107 \mathrm{~S} \mathrm{Ct}$ at 2539 (White dissenting).

115 See note 21 and accompanying text.

118433 US at 592 (plurality opinion of White). The death penalty was available for rape of an adult woman in only one state and was rarely imposed even there. Id at 595-596. Two additional states provided for capital punishment in the case of rape of a minor. 
survey of the mental state that legislatures and juries demanded before imposing capital punishment. ${ }^{117}$ In Tison, considerable weight was given to the fact that only a "small minority" of capital punishment jurisdictions reject the death penalty where the defendant was recklessly indifferent to human life. ${ }^{118}$

In Booth, however, the Court did not examine empirical evidence or discuss other state requirements and jury findings. External criteria that reveal why victim-related factors are irrelevant would seem as important as those criteria that show, for example, why the death penalty might be excessive for rape. If the Court had examined the empirical evidence, it would have found an overwhelming consensus that victim harm is a relevant sentencing consideration. ${ }^{110}$ Victim impact statements are employed by thirtyeight states as well as by the federal government. ${ }^{120}$

If deference to the legislature is to have any meaning, harm to the victim, and society's and the victim's desire to punish, must be considered fully pertinent to the sentencing decision. ${ }^{121}$ By failing to acknowledge this, the holding in Booth rejects any reasonable notion of legislative deference.

\section{The Criminal Law's Emphasis on Result}

Aside from the unexplained rejection of legislative deference, the most serious flaw in the Booth Court's reasoning is its failure to recognize that eligibility for the death penalty always depends upon the harm that results. ${ }^{122}$ Had the gun in Tison misfired, or had the father not pulled the trigger, the victims would have lived and the nontriggermen sons would not have been eligible for execution. Yet that the gun did not misfire is irrelevant to their culpa-

117458 US at 788-796.

$118 \mathrm{~S}$ Ct at 1688. In the non-capital context, see Solem v Helm, 463 US 277, 290-295 (1983) and Weems, 217 US at 380.

110 The Court did, however, justify the limitation of its holding to capital cases by acknowledging the "legislative judgment that the effect of the crime on victims should have a place in the criminal justice system." $107 \mathrm{~S}$ Ct at $2536 \mathrm{n} 12$.

120 See notes 5 and 6.

${ }^{221}$ Deference to legislative determinations of the appropriate reasons for punishment has always been part of the Court's jurisprudence. Justice Black, concurring in Powell $v$ Texas, stated, "the basic premise underlying the [defendant's] argument is that it is cruel and unusual to punish a person who is not morally blameworthy. I state the proposition in this sympathetic way because I feel there is much to be said for avoiding the use of criminal sanctions in many such situations. . . . But the question here is one of constitutional law. The legislatures have always been allowed wide freedom to determine the extent to which moral culpability should be a prerequisite to conviction of a crime." 392 US 514, 544-545 (1968) (citations omitted).

${ }^{122}$ Booth, $107 \mathrm{~S} \mathrm{Ct}$ at 2541 (Scalia dissenting). 
bility under a retributive theory. The sons were to be executed because of the result of their crime, a factor that is certainly as arbitrary and capricious as the suffering that a victim's family undergoes. Fortuitous factors, irrelevant to the offender's culpability, can always intervene to save the victim's and consequently the defendant's life.

This practical relevance of result is not limited to laws that differentiate between attempts and completed acts, but is pervasive in criminal law. The weakness in the Booth Court's reasoning is that it fails to recognize that the criminal law categorizes punishments according to the actual results. Thus, to reject the degree of harm inflicted as irrelevant, when divorced from the defendant's intentions, is to reject a principle that pervades the criminal justice system.

In fact, the prevalence of victim impact statements is one manifestation of the general increase in emphasis on results. ${ }^{123}$ The new Federal Sentencing Guidelines also provide an example of this trend. ${ }^{124}$ In an effort to reduce the sentencing discretion of trial judges, the Sentencing Commission designed a system in which the presence of specific objective factors increases the criminal's sentence. Harm or result is a prominent aspect of these factors. A comparison of potential sentences after two hypothetical robberies is illustrative. Suppose A, who has no criminal history, robs an expensive jewelry store, absconding with items worth $\$ 60,000$. In the course of the robbery, a patron of the store, seeing the gun A brandishes, faints and suffers minor injuries. One hour later, $\mathrm{B}$, also without a criminal history, decides to rob the same store. Fortunately for $\mathrm{B}$, the store is cleaned out, and despite his repeated threats to shoot the store owner, $B$ leaves with only $\$ 1,000$. Even if A and B have identical character traits and backgrounds, under the Federal Sentencing Guidelines, A is subject to a minimum of 63 months in prison, while $B$ is subject to a maximum of 46 months. ${ }^{125}$

One response, of some force, is that just because criminal law

${ }^{123}$ For an empirical study of judges' emphasis on harm, see Jolene C. Hernon and Brian Forst, The Criminal Justice Response To Victim Harm, Nat'l Institute of Justice, US Dept of Justice (May 1984).

${ }^{124}$ US Sentencing Commission, Federal Sentencing Guidelines and Policy Statements (1987).

${ }^{125}$ Whether the Federal Sentencing Guidelines are constitutional does not affect the point. The Guidelines are indicative of a sentiment that judges' discretion should be narrowed by increasing the importance of harm, and of the presumed legitimacy of punishing in proportion to harm. 
is somewhat arbitrary does not mean we should make it more arbitrary. Criminal sanctions are often categorized according to result, the argument goes, because a case-by-case, unbounded investigation of the defendant's culpability would yield more mistakes than it would correct. It may be that the thief who steals from a starving man is more "blameworthy" or culpable than the battered wife who kills her husband, but the criminal justice system may be incapable of consistency in making such determinations. Thus, bright-line categories are used, with the harm that the defendant caused often serving as a proxy for his culpability.

But this assumes that victim-related factors slipped into criminal law merely as a by-product of a system attempting to classify by culpability. The evidence is otherwise: the sanctions for vehicular homicide demonstrate that actual harm is widely perceived as a legitimate basis for punishment in and of itself. A defendant who kills a pedestrian by running a red light can receive imprisonment for involuntary manslaughter, whereas a defendant who merely runs a red light receives only a small fine. ${ }^{126}$ Clearly, the death of the pedestrian cannot be evidence that the driver was so much more careless than the non-homicidal driver that he deserves so large an increment of punishment. Moreover, the greater harm is not framed as a rebuttable presumption of greater culpability; the defendant cannot even litigate the issue. Although legislatures often narrow the discretion of courts by increasing the importance of result, as in the new Federal Sentencing Guidelines, this does not mean that reducing discretion is the only goal of emphasizing result. As the proliferation of victim impact statements indicates, there is a widespread belief that victim suffering is an important sentencing factor. ${ }^{127}$ Booth is therefore anomalous in a criminal system that systematically emphasizes result.

The focus on moral culpability, demanded by Booth and perhaps by the proportionality rule, is in tension with originalist constitutional theory, legislative deference, and the criminal law in general. In all probability, this tension is a consequence of an un-

${ }^{228}$ See Booth at 2540 (White dissenting). For example, the sanction in New York for "criminally negligent homicide" (causing the death of another person because of gross negligence) is from one to four years in prison. NY Penal Law § 125.10 (McKinney 1987). Reckless driving is a misdemeanor. NY Vehicle \& Traffic Law $\$ 1190$ (McKinney 1986). See also Commonwealth $v$ Welansky, 316 Mass 385, 55 NE2d 902 (1944) (reckless disregard of fire hazard resulting in several hundred deaths; defendant sentenced to $12-15$ years at hard labor).

${ }^{127}$ For example, the adoption of the Federal Victim and Witness Protection Act (cited in note 3 ), indicates a conscious belief that victim harm is of independent importance. 
resolved debate, both in the Court and in society, about the appropriate reasons for punishing a criminal. ${ }^{128}$ Booth appears to terminate the debate by constitutionalizing a retributive theory, at least in capital cases. ${ }^{129}$ One can seriously question the legitimacy of constitutionalizing retribution without any discussion of the depth and tension of the debate.

\section{Some Potential Justifications for the Mandated Retributive Philosophy}

The preceding section has argued that the Court's constitutionalization of retribution is at odds with utilitarian aspects of our criminal justice system. But there may be other ways to understand and justify the Court's position. This section discusses three possibilities.

\section{A. Culpability as a Necessary But Not Sufficient Condition}

The Court's Eighth Amendment jurisprudence could be interpreted to mean that "the death penalty can only be applied to the most culpable." It would not be inconsistent with this interpretation to say then that "the death penalty need not be applied to all of the most culpable." Factors such as potential for rehabilitation, whether the offender has a family to support, or the extent of harm caused by the crime could be employed to reduce the sentence given to a highly culpable offender, but not to increase the sentence of an offender of "lower" moral culpability. In other words, the required culpability would be a necessary but not always sufficient condition for the death penalty. This scheme would adequately distinguish the attempted murderer from the successful killer.

This would be a perfectly legitimate system, provided one ac-

${ }^{128}$ The extent to which the Court has oscillated on this issue at all levels of punishment severity can be seen by comparing Robinson v California, 370 US 660 (1962) (punishment for status of drug addiction violates Eighth Amendment because only wrongful conduct can be proscribed) with Powell $v$ Texas, 392 US 514 (1968) (conviction for public drunkenness upheld); Rummel $v$ Estelle, 445 US 263, 274 (1980) (life sentence imposed after a third nonviolent felony conviction was constitutional: "the length of the sentence actually imposed is purely a matter of legislative prerogative") with Solem v Helm, 463 US 277 (1983) (life sentence without parole is inherently disproportionate to the crime of passing a bad check even though defendant had seven prior nonviolent felony convictions); and finally Enmund with Tison. Except for Robinson, all of these cases were five-to-four decisions.

128 The Court's policing of the proportionality rule in non-capital cases has been rare and controversial. In only three cases has the Court found a non-capital sentence to be disproportionate: Weems, 217 US 349 (1910); Robinson v California, 370 US 660 (1962), and Solem v Helm, 463 US 277 (1983). 
cepts the relevance of utilitarian factors. It is not, however, the system set up in Booth. The offender in Booth was in the "most culpable" category, and certainly the Court would permit his execution in the absence of a victim impact statement. Thus, under the above scheme, the victim suffering should have been examined if it possibly could have reduced his sentence.

To illustrate this point, suppose three offenders, A, B, and C, all vicious contract killers, are hired by a criminal defendant to murder the prosecution's witnesses. A shoots a testifying police officer, but fortunately the officer is wearing a bullet proof vest and lives. B shoots and kills W, a much disliked former associate of the defendant who has turned state's evidence. $\mathrm{C}$ then shoots and kills the police officer, succeeding where $A$ failed. Suppose $W$ dies instantly, and had neither friends nor family, while the officer suffered for weeks before finally dying, and left four children in need of financial and emotional support.

$\mathrm{B}$ and $\mathrm{C}$ are presumably eligible for the death penalty, while $\mathrm{A}$ is not. But the Booth rule precludes a systematic distinction between $B$ and $C$. Why should it, when there is a systematic distinction between $\mathrm{A}$ and the others? The only difference between the three cases is the extent of victim suffering.

It seems that there are two internally consistent approaches available for sentencing $\mathrm{A}, \mathrm{B}$, and $\mathrm{C}$. First, one could admit the legitimacy of utilitarian factors and employ a system where culpability is necessary but not sufficient for the death penalty, as outlined above. This apparently was the approach taken by the Court in Jurek $v$ Texas, ${ }^{130}$ in which the likelihood of recidivism was held to be a legitimate sentencing criterion in capital cases. Alternatively, one could maintain that moral culpability is the only relevant factor, and thus distinctions between the three offenders are impermissible. Equally culpable defendants would be treated equally. Taking this approach is extremely difficult in practice, and the Court's attempts to do so, as in Booth, have failed.

\section{B. Frugality of Punishment}

A "frugality of punishment" theory is another possible justification for the dichotomy spawned by the Supreme Court's incomplete retributive philosophy. ${ }^{131}$ Under this theory, attempts are punished less than completed acts because there is little deterrence

${ }^{230} 428$ US 262 (1976). See section II.B.2.

131 See Schulhofer, $122 \mathrm{U} \mathrm{Pa} \mathrm{L} \mathrm{Rev} \mathrm{at} \mathrm{1562-1585} \mathrm{(cited} \mathrm{in} \mathrm{note} \mathrm{24).}$ 
value in giving an attempt stiff punishment. A killer intends that his crime be successful, and looks only to the sanction for the completed act when deciding whether or not to kill. Thus the state may as well save money and refrain from giving an unsuccessful offender extensive incarceration. As applied to the illustration above, an argument can be made that frugality requires reducing A's sentence, since his crime was unsuccessful, but does not mandate distinguishing between $\mathrm{B}$ and $\mathrm{C}$, since potential offenders are just as likely to be deterred by the penalty given one as the other, because in both cases the crime was "successful."

There are, however, serious theoretical flaws in the frugality justification. To name three: 1 ) it assumes that criminals hold the irrational belief that they will always be successful; 2) it is a rationalization of a system of punishment that originated for completely different reasons; and 3) it fails to explain adequately why penalties for non-intentional crimes are a function of harm. ${ }^{132}$ More importantly, the frugality justification is misplaced in the culpabilitydominated Eighth Amendment area: no Eighth Amendment case mentions it. Furthermore, the frugality justification is inapplicable in the death penalty context, since there is no reason to assume that not executing someone will save money.

\section{The Unique Nature Of The Death Penalty}

The Booth Court explicitly limited its holding to capital cases. ${ }^{133}$ The death penalty, because of its unique "severity and irrevocability," has been consistently deemed "qualitatively different from any other punishment."134 That a line of Eighth Amendment cases establishes a heightened procedural protection for capital defendants demonstrates that the Court is serious about this difference. Although there have been some recent intimations that the unique nature of the death penalty is no longer cast in stone, ${ }^{135}$ it remains embedded in the Court's jurisprudence.

${ }^{232}$ Id.

${ }^{133}$ Booth, $107 \mathrm{~S} \mathrm{Ct}$ at $2536 \mathrm{n} 12$.

${ }^{234}$ Spaziano v Florida, 468 US 447, 468 (1984) (Stevens concurring in part and dissenting in part).

${ }^{235}$ Justice Brennan, dissenting in Wainwright $v$ Witt, 469 US 412, 463 (1985) noted "the Court's increasing disaffection with the previously unquestioned principle endorsed by every member of this Court, that 'because of its severity and irrevocability, the death penalty is qualitatively different from any other punishment ...."' quoting Spaziano, 468 US at 468 (Stevens concurring in part and dissenting in part). In support of this contention, Justice Brennan cited Spaziano, 468 US at 461-464, Pulley v Harris, 465 US 37 (1984), and Barclay v Florida, 463 US 939 (1983). 
A frequent justification for greater procedural protections for capital defendants is the death penalty's complete irrevocability. ${ }^{136}$ Because mistakes are irreversible, greater reliability or accuracy is demanded. Although a prison sentence is irreversible in the sense that the years spent in prison cannot be returned, society is able to compensate the wrongly convicted defendant in a way that is impossible after execution. ${ }^{137}$ The problem with this argument is that the procedural protections afforded capital defendants are not employed in the guilt phase of the trial. To the extent we are concerned about executions being imposed erroneously on innocent parties, we should increase the due process protections applicable to the determination of guilt. ${ }^{138}$

On the other hand, to the extent we are concerned with the enhanced sentence being irreversible, we should be very concerned, since all sentences, capital or not, are effectively irreversible. There is no adequate procedure for reducing a perpetrator's sentence if facts are subsequently discovered revealing that, though he is still guilty, he was in reality less culpable than previously thought. An offender who, because of imperfect sentencing procedures, receives life imprisonment without parole instead of a five year imprisonment, will probably remain in jail for life unless evidence appears that casts doubt upon his conviction, as distinct from his sentence. ${ }^{139}$

The argument that the death penalty is unique in its severity has more force. Of course, simply because it is the most severe punishment does not mean it should be imposed only after satisfying a different and stricter set of procedural criteria. Any scheme of punishment has a maximum penalty, and no one argues that in states without capital punishment, the imposition of a life sentence

136 See Spaziano, 468 US at 468 (Stevens concurring in part and dissenting in part); Lockett v Ohio, 438 US 586, 604-05 (1978) (plurality opinion of Burger); Gregg, 428 US at 230 (Brennan concurring).

137 See Annotation, Compensation for Wrongful Conviction, 34 ALR4th 648 (1984); Comment, Compensation of Persons Erroneously Confined by the State, $118 \mathrm{U}$ Pa L Rev 1091 (1970).

138 An analogy can be drawn to the right to counsel. The Court has held that indigent misdemeanor defendants have an automatic right to counsel under Gideon $v$ Wainwright, 372 US 335 (1963), only if the proceedings actually result in imprisonment. Scott $v$ Illinois, 440 US 367 (1979). In other words, the extent of procedural protection at the guilt phase of the trial depends upon the severity of the sentence.

130 This is all the more true because of the absence of comparative proportionality review in non-capital cases. See note 71 . Clemency is available in rare situations, but there is no institutionalized mechanism to re-examine sentences. The point is not that irrevocable sentences are good, but merely that the predominance of such irrevocable non-capital sentences subverts the Court's insistence that irrevocability is unique to the death penalty. 
necessitates satisfying stricter criteria than the imposition of fifty years imprisonment. But there is widespread belief that the death penalty is significantly more severe than any other sanction in our system. ${ }^{140}$ It is perhaps an exaggeration to assert, as Justice Stewart did, that death "differs more from life imprisonment than a 100-year prison term differs from one of only a year or two,"141 but taking life away changes both the manner and effect of punishment to such an extent that it should not be seen as just another sanction.

Nevertheless, the distinction between capital and non-capital cases, however valid, does not apply to the relevance of victim harm. The Booth case held that victim impact statements were inadmissible in the capital sentencing phase of a trial. If this is viewed as an evidentiary rule, the limitation to capital cases is perhaps reasonable: because of the potential prejudicial effect to the defendant that a victim impact statement might engender, the liberal rules of evidence applicable to sentencing procedures ${ }^{142}$ can arguably be bypassed because of the capital defendant's heightened procedural rights. This result is analogous to many of the other procedural demands applicable in capital cases. ${ }^{143}$

Insofar as the Booth Court's reasoning deems victim harm an irrelevant consideration, however, the limitation to capital cases is unsupported by the reasons underlying the distinction. All the other cases decided under the "arbitrary and capricious" branch of Eighth Amendment doctrine mandate procedures that presumably will help ensure that only those who are most deserving will be executed; Booth actually decides that those who cause more harm are not more deserving, and that the issue of desert is the only relevant issue. Booth is not a decision designed to prevent a high risk of factual error, so much as a substantive decision that certain determinations by a sentencing authority, even if factually correct, are irrelevant. As such, it seems fully applicable to non-capital cases.

Put another way, if evidence is wholly irrelevant, does it not remain so regardless of the penalty? Perhaps the heightened procedural rights applicable in capital cases are not employed in noncapital cases because of principles of deference to legislatures. Con-

140 That large sectors of society vehemently oppose capital punishment is an itself indication of its perceived severity.

${ }^{141}$ Woodson $v$ North Carolina, 428 US 280, 305 (1975) (plurality opinion of Stewart).

${ }^{142}$ See Williams $v$ New York, 337 US 241 (1949).

${ }^{143}$ See section II.A.1. 
sistently applying a rule excluding fortuitous results or victim related factors to non-capital situations would be difficult, if not impossible, because the prevalence of such factors is embedded in non-capital sentencing. But this is not a case where the Court's deference to the legislature would serve any purpose if indeed harm is irrelevant. Banning victim impact statements is a procedural requirement that is easy to administer; it either should always apply, or never.

\section{Conclusion}

Three points may be made about Eighth Amendment capital jurisprudence in relation to victim harm. First, the Court's approach to punishment, at least in the death penalty context, is essentially retributive despite protestations to the contrary. The trend in the proportionality cases and the entire thrust of modern death penalty jurisprudence mandate that culpability be the cornerstone of a valid sanction. This implicitly rejects utilitarian theories such as deterrence and vengeance, and makes Booth seem doctrinally correct.

Second, the Court in Booth did take a small step beyond the proportionality rule (which requires a gross comportment with culpability) to a requirement that the specific sentencing decision be made with reference only to culpability-that is, the decision must be solely retributive. This development is theoretically supportable given the acceptance of proportionality, and is doctrinally buttressed by a considerable amount of dicta in cases such as Enmund ${ }^{144}$ and Zant $v$ Stephens. ${ }^{145}$ But certain utilitarian justifications still appear to be tolerated, a fact difficult to square with Booth. In particular, the development casts considerable doubt upon Jurek $v$ Texas, ${ }^{146}$ which went unmentioned in Booth.

Finally, the Court's partial rejection of utilitarian theories such as vengeance is unjustified. Although as a theoretical matter there is considerable room for debate about the appropriate reasons for punishment, as a matter of constitutional interpretation the Court is misguided. The proportionality rule should operate only as a gross check on the severity of sanctions and not as a mandated focus on culpability, and Booth, insofar as it precludes considerations of victim suffering, should be overruled. 
. 